\title{
The giants beneath: Cultural memory and literature in Kazuo Ishiguro's The Buried Giant
}

\begin{abstract}
Drawing on the approaches of discussing the concept of memory within literary studies, as delineated by Erll and Nünning (2005), this paper examines The Buried Giant by Kazuo Ishiguro as a site of 'memory of literature' and as a 'medium of cultural memory'. Reworking the well-known cultural motif of quest, Ishiguro's novel also evokes associations with the medieval literary tradition, especially Sir Gawain and the Green Knight, and contemporary fantasy literature, understood as a mode of writing rather than a formula. It is also argued that by referring to a fictional past of Arthurian romances rather than historiography, the novel comments on the role of literature in creating cultural remembrance, becoming a specific metaphor of its processes.
\end{abstract}

Keywords: Kazuo Ishiguro, The Buried Giant, memory of literature, cultural memory, fantasy, J.R.R. Tolkien, Sir Gawain and the Green Knight.

Ten years before the publication of The Buried Giant, Kazuo Ishiguro, who had written five novels by then, was described by Peter Childs as an author concerned "with individuals scanning their pasts for clues to their sense of identity, loss, or abandonment" (23). In a more recent study Wojciech Drąg observes that the narrators of Ishiguro's novels are motivated to revisit their pasts by the following desires: to tell about their loss, to forget or deny it, or to return to the time before the traumatic experience (2-3). In all his novels Ishiguro revisits the theme of memory, and he seems to be as fascinated and haunted with it as his narrators are with their past experiences. He does not, however, refrain from experimenting with different literary genres, employing the conventions of the detective novel in When We Were Orphans (2000), science fiction and dystopia in Never Let Me Go (2005), and fantasy in The Buried Giant (2015). This combination of thematic consistency and openness towards various literary traditions draws attention to the relationship between memory and literature, suggesting their inherent interconnectedness. As a novel that focuses not only on individual but also collective past, The Buried Giant is indebted to the genre of fantasy, which in J.R.R. Tolkien's understanding of its foundations draws so much of its inspiration from earlier literary and non-literary phenomena and is essentially mythopoeic. 
The concept of memory, both individual and collective, has been examined over the last few decades from a variety of angles, proving that the field of memory studies is open to contributions from many different disciplines. This interdisciplinary character of research on memory is evident in a collection of essays edited by Astrid Erll and Ansgar Nünning (2008), in which various methodological perspectives and practices meet to examine the concept of cultural memory - an umbrella term used to refer to "the interplay of present and past in socio-cultural contexts" (Erll 2008 , 2). As one of the media in which memory can be 'stored' and through which it can be transmitted, literature has obviously played an important role in the representation of the past - from individual experiences to national history. A literary text, therefore, can be seen as a specific way of memory-making, contributing significantly to the ways in which the past is constructed. In fact, both literature and memory rely on similar processes of selecting, organizing and arranging individual elements to form a coherent whole, and these similarities include "the forming of condensed 'memory' figures and a tendency towards creating meaning through narrativization and genre patterns" (Erll 2011, 145). These peculiar meeting points can be examined in a more systematic way according to Erll and Nünning (2005), who propose three approaches to discuss the notion of memory within the field of literary studies. These can be broadly characterized as 1) memory in literature, 2) memory of literature, 3) and literature as a medium of cultural memory.

The first of these problems, also referred to as the "mimesis of memory" (Erll and Nünning 2005,265 ), i.e. the representation of the nature, workings and functions of memory in literary texts, has been examined in the present issue by Edyta Lorek-Jezińska, who focuses on the psychological processes of remembering and forgetting traumatic experiences and their ethical dimensions in Ishiguro's novel. However, the title metaphor of the 'buried giant' seems to refer not only to the repressed traumatic memory, which constitutes the main theme of the narrative, but also to the foundations that lie beneath its structural framework. This article, therefore, aims to examine the other 'giants' lurking beneath the surface of Ishiguro's novel, which consciously plays with and reworks earlier literary traditions, including mythical, medieval and fantasy narratives, to reveal its preoccupation with the ways literature participates in the processes of cultural remembrance.

\section{Memory of literature}

If literature can metaphorically possess its own memory, literary texts can 'remember' other texts. Examining the memory of literature can thus focus on the recurrence of topoi and various intertextual relations as well as on the development of literary genres, perceived as repositories of cultural memory, which is in turn shaped by them. Importantly, the memory of literature does not rely on passive transmission as writing is "both an act of memory and a new interpretation, by which every new text is etched into memory space" (Lachman, 301). Such an approach to fiction is evident in The Buried Giant, which incorporates a number of well-recognized cultural motifs within its structure, as well as evokes associations with medieval literary tradition and resonates with contemporary fantasy literature. 
Probably the most prominent of the motifs reworked by Ishiguro is the pattern of quest in its three interrelated manifestations. The first quest is undertaken by an elderly couple, Axl and Beatrice, to find their son, rediscover memories and, ultimately, face death. The second one belongs to Wistan, a virile Saxon warrior sent by his king to kill the she-dragon, named Querig, whose magical breath literally causes the mist that takes away people's memories. By slaying her, Wistan aims to remove the veil of oblivion from the community that has forgotten the traumatic experience of war, or rather ethnic cleansing executed by Arthurian knights against the Saxons. The last quest is an ambiguous mission of Sir Gawain, entrusted to him by King Arthur, to protect the dragon, whose lasting presence on the one hand causes amnesia, but on the other one ensures relative peace in a society which has forgotten its painful past. Such an organization of the plot clearly derives from mythological narratives, whose fundamental structure has been identified and defined by Joseph Campbell as monomyth - the universal pattern of mythological adventure or hero's journey, which can be divided into three key stages of separation (or departure), initiation, and return. In numerous myths worldwide, Campbell observes, "[a] hero ventures forth from the world of common day into a region of supernatural wonder: fabulous forces are there encountered and a decisive victory is won: the hero comes back from this mysterious adventure with the power to bestow boons on his fellow man" (28). In this optimistic pattern of myth and fairy-tale, adopted in both medieval chivalric romances and numerous contemporary fantasy novels, the adventures of the hero in the fantastic realm are crucial to his spiritual, moral, or emotional development and eventually result in the well-being of the community at microcosmic and/or macrocosmic levels (cf. Campbell, 33). In The Buried Giant the basic pattern of monomyth is followed. The characters roam their way in pursuit of their goals while certain features of the semantically significant landscape stir their memories, bringing back chaotic recollections that are made sense of only at the end of the journey. Yet the novel stands in a dialogic relationship to the traditional narratives rather than repeats or recounts them, especially in its ambiguous depiction of the results of the accomplishment of the quest.

$\mathrm{Axl}$ and Beatrice fail to achieve the initial purpose of their mission as their son turns out to be long dead, but they do regain memories of their life together, including its harshest moments - Beatrice's unfaithfulness to her husband, Axl's subsequent anger, and the couple's reconciliation, which results from covering the problem with a veil of silence rather than forgiveness. This personal buried 'giant' leads to the suppression of another trauma when Axl, out of vengeance, prevents both of them from visiting the grave of their son and mourning his death: "It was just foolishness and pride. And whatever else lurks in the depths of a man's heart. Perhaps it was a craving to punish, sir. I spoke and acted forgiveness, yet kept locked through long years some small chamber in my heart that yearned for vengeance" (Ishiguro, 357). The "small chamber" in his heart, where the grudge has been secretly buried for years, is finally opened upon Querig's death, and Axl discovers that in the course of time, without even realizing that, he has finally managed to forgive his wife: "And I think now it's no single thing changed my heart, but it was gradually won back by the years shared between us... A wound that healed slowly, but heal it did" (Ishiguro, 357). Ishiguro's 
message that time heals all wounds verges on the banal here; and yet the conclusion of the novel challenges reading his narrative as a truly "eucatastrophic tale"12, which is for Tolkien "the true form of fairy-tale," whose most important function is to give readers "the joy of the happy ending" and consolation (2006a, 153). No such solace is offered here. Having regained their memories and granted each other forgiveness, $\mathrm{Axl}$ and Beatrice are not true winners, and their victory brings little change to their fate. No matter how strong their love has proved to be, they cannot undertake the final journey together. The passage to the otherworld, envisioned in the novel as a mysterious island, where everyone "walks ... alone, his neighbours unseen and unheard" (Ishiguro, 350), cannot be shared. And so the novel closes with the image of a ferryman, whose name is never uttered but could be Charon (Greek mythology), Manannán (Irish mythology) or Urshanabi (Mesopotamian mythology), ferrying Beatrice to the island while Axl remains on the shore alone. Just as the quest, marriage and life end, the story reaches its conclusion, leaving readers with sadness rather than joy. The implications of Wistan accomplishing the quest do not provide eucatastrophe either, which is emphasized by the image of the hero himself, who appears "overwhelmed and not in the least triumphant" (Ishiguro, 338) upon slaying the dragon. Although his belief in his mission is genuine and the reader is led to admit that "old wounds [cannot] heal while the maggots linger so richly" (Ishiguro, 327), the victory seems hollow. There is nothing heroic in his clash with Querig, which is sketched as a creature on the verge of death rather than a terrifying monster:

Her posture - prone head twisted to one side, limbs outspread - might easily have resulted from her corpse being hurled into the pit from a height. In fact it took a moment to ascertain this was a dragon at all: she was so emaciated she looked more some worm-like reptile accustomed to water that had mistakenly come aground and was in the process of dehydrating... The remnants of her wings were sagging folds of skin that a careless glance might have taken for dead leaves accumulated to either side of her. (Ishiguro, 325)

Here again, Ishiguro consciously diverts from a dragon-slayer narrative, which is typically based on a combination of the following elements: a fight to free a woman (e.g. the legend of Saint George), a struggle for treasure (e.g. Fafnir in Norse mythology), and a battle to save the slayer's people (e.g. Beowulf). This departure serves to highlight the inherent ambiguity of the construction of Querig - a dragon that paradoxically embodies the power and perils of forgetting simultaneously. In Ishiguro's take on the tale, the princess is freed from amnesia and given back her recollections but has to die anyway; the treasure of memories turns out to be a heavy burden; and the act of slaying the dragon is doomed to bring chaos not peace. Although one monster is killed, another one, probably even more ominous, is awoken:

12 Tolkien understands eucatastrophe as a 'good catastrophe', i.e. an unexpected turn of events at the end of a story that appears to be doomed to a tragic ending. It prevents the unfortunate fate of the protagonist and offers joy, often mixed with tears. For Tolkien eucatastrophe does not exclude the possibility of sorrow or failure, yet ultimately constitutes a happy ending, and offers consolation, relief and a glimpse of truth about the nature of things (Tolkien 2006a, 153-154). 
The giant, once well-buried, now stirs. When soon he rises, as surely he will, the friendly bonds between us will prove as knots young girls make with the stems of small flowers. Men will burn their neighbours' houses by night. Hang children from trees at dawn. The rivers will stink with corpses bloated from their days of voyaging. (Ishiguro, 340)

It is implied over and over again that while keeping Querig alive prevents justice and covers up the atrocities of war, killing her will result in perpetuating the cycle of violence and vengeance, rather than reconciliation. Thus, employing the pattern of myth or fairy tale serves to provide neither comfort nor a straightforward answer, but poses a difficult question about when to silence and when to confront the past. The once-upon-a-time, allegorical setting of the novel is in fact a conscious attempt to shift the focus of the narrative from personal to social past and from individual to collective memory. As a result, Ishiguro's tale refrains from pointing to any historical genocide and trauma, but simultaneously encompasses all of them within its scope. In terms of emotional involvement, The Buried Giant distances the readers from the characters, sketched as Everyman figures, actants rather than acteurs in Algirdas Julien Greimas' nomenclature, and yet it appeals to our perception of fairy tales as stories of universal significance and derives its power from them.

\section{'Remembering' Sir Gawain and the Green Knight}

Still, the text that The Buried Giant 'remembers' particularly well is the late fourteenth-century chivalric romance Sir Gawain and the Green Knight - a source of inspiration to which Ishiguro openly admits in an interview with Lorien Kite, referring in particular to the passages that describe the wanderings of Sir Gawain: "I particularly liked the fact that ogres were mentioned just in passing, as though they were like untamed bulls, an everyday hazard that Gawain had to contend with." The treatment of the fantastic element in the novel is indeed more akin to the handling of the matter by the Gawain poet, who simply observes "So many were the wonders he wandered among / That to tell but the tenth part would tax my wits" (1l. 718-719), than to the conventions adopted by contemporary fantasy novelists, for whom creating a convincing and elaborate detailed fictional world is usually a task of prime importance. In Sir Gawain the marvels and wonders are taken for granted as a natural setting of Arthurian Britain (11. 24-25), becoming a part of its founding myth. Likewise, in The Buried Giant ogres, pixies, and dragons are a part of the world, yet no explanation of their existence or provenance is given, as if they personified what is unknown and inexplicable with no need for further details. Like the Gawain poet, who as Tolkien observes, "was not interested in the fairy-tale or in romance for their own sake" (2006b, 97), Ishiguro is not concerned with fantasy for the sake of the fantastic. It is interesting, in fact, that some reflections made by Tolkien about Sir Gawain in his lecture read like a valid commentary on Ishiguro's novel as well ${ }^{13}$.

13 This is not to suggest that Tolkien's lecture could have been among Ishiguro's inspirations, but to reveal a similar sensitivity of both authors, manifesting itself in their approach to the source materials that are creatively reshaped 
One of Tolkien's observations on Sir Gawain, which can be applied to The Buried Giant, is that it is a "rooted" work "made of tales often told before and elsewhere, and of elements that derive from remote times, beyond the vision or awareness of the poet" (2006b, 72). Yet, such a rooted work never merely repeats the plots, motifs and symbols, but employs them to convey ideas important for a new audience, "the changed minds of a later time" (2006b, 72), which can differ considerably from those that have originally produced them. This comment seems to be crucial to grasp the nature of the correspondences and echoes in which these works are entangled. Although the Gawain poet inherits the chivalric tradition of the High Middle Ages together with "the air of the Faerie" (Tolkien 2006b, 83) and assumes a certain familiarity of his audience with the subject matter of Arthurian romances of Chrétien de Troyes, the narrative is not based on a single French original, but combines elements of different sources (Burrow, 79-80). Despite recalling this earlier tradition, Sir Gawain is a product of its own times and engages in the late medieval process of "morally corrective reworking" (Gilbert, 161), inviting both Gawain and the audience to reconsider the nature of courtly games and chivalric tests. According to Tolkien's interpretation of the poem, the whole tale is fashioned to depict a dilemma, structured as temptation and faced by the protagonist, who must choose between courtesy and Christian morality. Violating the rules of the courtly Exchange Game imposed by Lord Bertilak, who finally turns out to be the Green Knight himself, through accepting the green girdle from Lady Bertilak, Gawain manages to refrain from adultery and keeps to the 'real' Christian virtues, coming to understand that the rules of courtesy are not crucial for salvation (Tolkien 2006b, 89-95). Yet, there seems to be a certain ambiguity inherent in the poem that causes the ongoing critical discussion about its meaning. After all, Gawain himself is ashamed of his deceitful act and returns to Camelot wearing the girdle as a sign of his cowardice and failure to keep the promise given to Lord Bertilak.

In The Buried Giant, Sir Gawain, the protector of the dragon and collective amnesia, is an aged shadow of his fourteenth-century self - a geriatric knight wearing armour that is "frayed and rusted", in a tunic that "once white now showed repeating mending", with "several long strands of snowy hair [that] fluttered from an otherwise bald head" (Ishiguro, 119), which contrasts sharply with the figure of the young and vigorous knight glistening in red armour from the original. Supposed to keep peace by suppressing memory of the atrocities of war, his mission is, nevertheless, doomed to failure, which the readers are made to realize the moment they juxtapose his image with that of the virile Wistan. Ishiguro's Gawain does not wear a girdle that implies a diminution of his knightly virtues, yet the ambiguity of his moral code is well rendered in the two chapters that contain his "reveries", expressed as a first-person interior monologue, and distinct from the remaining part of the narrative in their stream of consciousness quality. The reveries reveal Sir Gawain to hold more memories than any other character of the novel, even though his recollections are chaotic and not structured into a coherent narrative. He is depicted as recalling his active participation in the genocide of the Saxons and seeing this act as the only way of preventing further war, yet a part of

for the needs of their narratives. 
him does not want to admit the truth, even when he is openly accused of murdering the innocents. "A slaughterer of babes. Is that what we were that day?" (Ishiguro, 244), he wonders.

Relying on a certain arbitrariness fundamental to the original poem itself, Ishiguro's reworking of the Gawain figure illustrates the author's tendency to explore the problem central to his narrative from a variety of perspectives. Ishiguros's Gawain is a loyal knight determined to fulfil his mission even in the face of death, but his attitude raises questions about whether his loyalty has been appropriately invested and whether his cause is indeed worth fighting for. There is also weariness in Sir Gawain, who fathoms the futility of his task and senses that his forthcoming duel with Wistan will inevitably result in his own death. The chapters devoted to his reveries purposefully stand out from the rest of The Buried Giant in terms of the narrative mode, which mirrors the flow of the protagonist's thoughts. As such they illustrate one more aspect of memory making. If the journey of Axl and Beatrice can be interpreted as a quest for one's own identity that requires dealing with individual traumatic experience, and the mission of Wistan as looking for justice and historical truth that has been suppressed, Gawain's main goal seems to be to rationalize the violence committed in the past. The reveries, therefore, shift the emphasis from the depiction of psychological processes typical for victims who need to regain their past, to those employed by the perpetrators of violence to justify its use.

\section{The fantasy mode}

The relationship of The Buried Giant with the tradition of fantasy literature should be perceived not as adherence to the rules established in the popular literature genre, but rather as a (re)discovery of its potential for spreading the memory of literature akin to Tolkien's creative strategies. As works written by a philologist and medievalist, Tolkien's own novels are also immensely 'rooted' and imaginatively draw on a wide range of Scandinavian myths and sagas as well as on Old English and medieval literature to shape meanings for twentieth-century minds. More importantly, however, at the heart of his creative approach, underlying The Hobbit, The Lord of the Rings, and The Silmarillion, lies the concept of "sub-creation", i.e. the process of building a Secondary World (with its myths, history, and geography) so consistent and coherent that it would command Secondary Belief (Tolkien 2006a, 139-140). In this context, the author of fantasy becomes a sub-creator, whose fictional world-building emulates the primary act of creation performed by God, and as such can offer Recovery, or "regaining of a clear view" (Tolkien 2006a, 146), enabling its readers to avoid cognitive stereotypes and rediscover the marvels and wonders of the primary reality. Tolkien's mythopoeic activity is also aimed at providing Escape, which is not simply 'escapist' but understood as turning away from the problems of modernity (progress, mechanization, mass production, death) and directing attention towards the values of the past (communion with nature, stable order of moral values, immorality) (2006a, 151-152). Thus, his works lovingly embrace the fantastic to tell tales of courage and fellowship, temptation and resistance, fate and free will, sin and redemption, and above all hope. Tolkien's grand project has definitely redefined the conventions of the fantastic literature, becoming a prototypical centre for numerous followers - some of whom limited themselves to the 
nearly mechanical repetition of tropes and motifs while others proposed alternative and often polemical solutions. By the time of the publication of The Buried Giant, fantasy had become a popular genre, divided into numerous subgenres, theorized, and academically examined.

Kazuo Ishiguro's venture into this territory has caused a stir, inspiring a considerable discussion on the status of fantasy literature in relation to literary fiction, and made the author himself unsure of the reception of the novel: "Will readers follow me into this? Will they understand what I'm trying to do, or will they be prejudiced against the surface elements? Are they going to say this is fantasy?" (quoted in Alter). These doubts seem to imply that Ishiguro intuitively attempts to go beyond the surface elements of fantasy, aiming for something deeper and more all-encompassing. Rejecting the concept of 'fantasy as formula' that is defined by Brian Attebery as a certain commercial storytelling recipe "restricted in scope, recent in origin, and specialized in audience appeal" (2), whose success depends on predictability and consistency with other works marketed as such, the author of The Buried Giant fully embraces 'fantasy as a mode' that takes in "all literary manifestations of the imagination's ability to soar above the merely possible" (2), originally created as collective literature, whose symbols were shared by whole societies and cultures. Consequently, his novel may disappoint the readers accustomed to the high fantasy or epic fantasy strategies that have come to rely on elaborate world-building, fast-moving action, detailed descriptions of sword-fights, and magic.

Despite this The Buried Giant remains surprisingly close to the tradition of story-telling that lies at the heart of Sir Gawain and Tolkien's narratives, deriving its power from being rooted in earlier tales and yet telling them anew and shifting the emphasis to engage in moral or philosophical questions that preoccupy their teller. While Sir Gawain employs the formula of a romance to study temptation on a plane of Christian morality, Lord of the Rings examines the temptation to submit to the corruptive power symbolized by the One Ring. The Buried Giant, in turn, is fashioned to offer questions - rather than answers - on the temptation to forget, and explores moral and psychological themes we are more accustomed to being addressed by realistic or autobiographical novels and memoirs. The intended vagueness of the novel contrasts sharply with Tolkienian mythopoeic sub-creation, implying perhaps that Ishiguro strives for creating disbelief, rather than secondary belief. Consequently, The Buried Giant offers neither escape nor consolation, and if any clear view is regained or recovered on reading the novel, it concerns the innate ambiguity of all narratives that pertain to the past, exposing the strategy of silencing certain voices to highlight others.

\section{Literature as a medium of memory}

The choice of the novel's structural framework, derived from myth, fairy tale and medieval romance, seems particularly suited for exploring the issues pertaining to collective memory, which is after all perpetuated through literature as well. By referring to the legendary Matter of Britain, as reflected in the fourteenth-century poem rather than historiography, The Buried Giant seems to draw attention to the fictionalising aspect of memory-making. The manner in which Ishiguro adopts the elements for his tale mirrors the way both individual and collective memories are made. In the last chapter of the story it turns out that the narrator of the tale is the nameless ferryman, 
the timeless death figure, who pieces the story together from the confessions of people he takes to the otherworld, represented in the novel by Axl and Beatrice. The boatman is the only person who can see the whole picture and give his tale at least a veneer of objectivity, which implies that no matter how important the memories are for individual identity, they will always remain subjective, fragmentary, and different from the collective ones, recorded as history. Taking into account that creating any narrative is a selective process, the reader is led to conclude that both individual experiences and collective past are subject to fictionalisation, narrativization and interpretation the processes in which literary transmission plays an important role.

The quests undertaken by Sir Gawain and Wistan are mutually exclusive and may be seen as attempts to impose on the audience equally contradictory narratives, created by victors and victims respectively. The rivalry between the two knights can be then understood not only as a conflict between two different approaches to remembering the past, but also as a clash for the control of the historical narrative. While it is difficult to sympathize with Gawain's design of the past that excludes the victims' point of view, Wistan, who wins the duel, does not simply aim to add a new dimension to the existing tale. On the contrary, as a new victor, he intends to change history completely, eradicating all memory of the Brits, even from the landscape: "And country by country, this will become a new land, a Saxon land, with no more trace of your people's time here than a flock or two of sheep wandering the hills untended" (Ishiguro, 340). Lacking both historical monuments and narrative to testify to their past, the Britons will fall into oblivion, suffering from the same kind of amnesia that characterised Wistan at the beginning of his quest, and the whole cycle will probably repeat itself over and over again. Ishiguro recognizes that this is a perpetual process, in which the canon of "memory sites", understood as both geographical locations, cultural artefacts and literary texts, is never stable but subject to constant revision by groups who aim to assert their own identity through replacing, shifting, or revising dominant representations of the past (Rigney, 345-346).

Apparently distancing the readers from the narrative through its post-Roman background, episodic quest structure, symbolical characters and reliance on earlier texts, the narrative technique adopted in The Buried Giant paradoxically reduces the gap between its remote setting and modernity through exposing its own fictionality and fashioning itself as an oral tale. This orality is emphasized from the opening sentence by addressing the reader with the second-person pronoun: "You would have searched a long time for the sort of winding lane or tranquil meadow for which England later became celebrated" (Ishiguro, 3). Such a beginning forces the readers to identify themselves as familiar with this "later" England, yet eager to listen to the legendary story of its origins. At various points of the narrative, we are reminded that the tale is meant for a contemporary audience who notice that no attempt is being made at either representing historical reality or sub-creating a fully-believable fictional secondary world that would facilitate immersion in the story. Instead, the story-teller presents the fictional world in terms understandable to a modern reader, for instance when he compares "a tall fence of tethered timber poles" to "giant pencils" (Ishiguro, 53), or a village longhouse to "a rustic canteen" (Ishiguro, 83). Such a strategy 
of inviting readers to visualize historically distant settings in terms of contemporary images is consistent, though not overused, and culminates when the narrator destroys the illusion of the audience being just listeners and makes them unnamed participants of the story that would inevitably take place in a different place at a different time:

Some of you will have fine monuments by which the living may remember the evil done to you. Some of you will have only crude wooden crosses or painted rocks, while yet others of you must remain hidden in the shadows of history. You are in any case part of an ancient procession, and so it is always possible the giant's cairn was erected to mark the site of some such tragedy long ago when young innocents were slaughtered in war. (Ishiguro, 305)

Drawing his readers into the tale while simultaneously distancing them from it seems to lie at the heart of Ishiguro's enterprise, indicating his deep understanding of the complexity of the role of a literary work in cultural remembrance. Certain texts, printed and reprinted over and over again, can be seen as more formative than others. Like Sir Gawain and the Green Knight or Lord of the Rings, they become "textual monuments" (Rigney, 349), which not only shape our perception of the past and literature itself, but also reinforce the feeling of belonging to a given community familiar with these works in the present. Yet, as such they still remain open to new readings, adaptations and appropriations, becoming building blocks for new narratives. When a work built of such blocks emerges, it can actively participate in spreading the plots, motifs, and topoi in different media or to different audiences. It can also become a "catalyst" (Rigney, 351) that draws attention to the new topics that were earlier neglected. Such catalysing power seems to be inherent in The Buried Giant, which does not simply remake the earlier texts to make them more up-to-date with contemporary tastes, but refashions them to explore ideas related to contemporary psychology, trauma, and the processes of remembrance.

\section{Conclusion}

While The Buried Giant participates in reinterpreting an earlier literary tradition, it does not do so for the sake of intertextual games only, but is engaged in posing questions pertinent to philosophy, psychology and ethics. It actively 'remembers' and exposes the kernels of previous narratives, like the plot outline, a bold character, an image, etc., yet is not concerned with creating a fictional world that would be fully convincing to the readers. It remains a text that stubbornly lingers between fairy tale, romance and fantasy to draw attention to the ideas that have always preoccupied Ishiguro rather than the story itself, unveiling complicated relationships between individual and collective memories, remembering and forgetting, past and present. Instead of referring to a particular historical moment that would necessarily evoke emotional response, The Buried Giant universalizes its message to refer to all and any 'giants' individuals, communities and countries have buried and then, wittingly or not, uncovered. Simultaneously, by referring to the quasi-historical but essentially fictional past of the Arthurian romances, Ishiguro draws his readers' attention to 
the role of literature in preserving, spreading and shifting the focus of cultural memories, the novel becoming a specific metaphor of the processes involved in cultural remembrance.

\section{References}

Alter, Alexandra. 2015. "For Kazuo Ishiguro, 'The Buried Giant' Is a Departure." The New York Times 19 Feb. 2015. 21 March 2016. https://www.nytimes.com/2015/02/20/books/for-kazuo-ishiguro-the-buried-giant-is-a-departure.html.

Burrow, J.A. 2009. “The Fourteenth-century Arthur." The Cambridge Companion to the Arthurian Legend. Ed. Elizabeth Archibald and Ad Putter. Cambridge: Cambridge University Press, 69-83. Campbell, Joseph. 2004 [1948]. The Hero with A Thousand Faces. Princeton, NJ: Princeton University Press.

Childs, Peter. 2005. Contemporary Novelists. British Fiction Since 1970. Basingstoke; New York: Palgrave Macmillan.

Drąg, Wojciech. 2014. Revisiting Loss: Memory, Trauma and Nostalgia in the Novels of Kazuo Ishiguro. Newcastle upon Tyne: Cambridge Scholars Press.

Erll, Astrid, and Ansgar Nünning. 2005. "Where Literature and Memory Meet: Towards a Systematic Approach to the Concepts of Memory in Literary Studies." Literature, Literary History, and Cultural Memory. REAL: Yearbook of Research in English and American Literature 21. Ed. Herbert Grabes. Tübingen: Narr, 265-98.

Erll, Astrid, and Ansgar Nünning, eds. 2008. Cultural Memory Studies. An International and Interdisciplinary Handbook. Berlin; New York: Walter de Gruyter.

Erll, Astrid. 2008. "Cultural Memory Studies: An Introduction." Cultural Memory Studies. An International and Interdisciplinary Handbook. Ed. Astrid Erll and Ansgar Nünning. Berlin; New York: Walter de Gruyter, 1-15.

Erll, Astrid. 2011. Memory in Culture. Trans. Sara B. Young. Basingstoke; New York: Palgrave Macmillan.

Gilbert, Jane. 2009. "Arthurian Ethics." The Cambridge Companion to the Arthurian Legend. Ed. Elizabeth Archibald and Ad Putter. Cambridge: Cambridge University Press, 154-170.

Ishiguro, Kazuo. 2015. The Buried Giant. London: Faber \& Faber.

Kite, Lorien. 2015. "Literary Life: Kazuo Ishiguro Interview." Financial Times 6 March 2015. 20 Feb. 2016. https://www.ft.com/content/24786502-c29e-11e4-ad89-00144feab7de

Lachmann, Renate. 2008. "Mnemonic and Intertextual Aspects of Literature." Cultural Memory Studies. An International and Interdisciplinary Handbook. Ed. Astrid Erll and Ansgar Nünning. Berlin; New York: Walter de Gruyter, 301-310.

Rigney, Ann. 2008. “The Dynamics of Remembrance: Texts Between Monumentality and Morphing." Cultural Memory Studies. An International and Interdisciplinary Handbook. Ed. Astrid Erll and Ansgar Nünning. Berlin; New York: Walter de Gruyter, 345-353.

Sir Gawain and the Green Knight. 1967. Transl. Marie Boroff. New York: W. W. Norton \& Company, Inc. 
Tolkien, J.R.R. 2006a [1983]. “On Fairy-Stories.” The Monster and the Critics and Other Essays. Ed. Christopher Tolkien. London: HarperCollinsPublishers, 109-161.

Tolkien, J.R.R. 2006b [1983]. "Sir Gawain and the Green Knight." The Monster and the Critics and Other Essays. Ed. Christopher Tolkien. London: HarperCollinsPublishers, 72-108. 